\title{
IDENTIFIKASI HAMBATAN MAHASISWA DALAM PELAKSANAAN PEMBELAJARAN BIOLOGI SECARA DARING SELAMA PANDEMI COVID-19 DI KABUPATEN JEMBER
}

\author{
Dewi Hariyanti ${ }^{1}$, Arinal Haq ${ }^{1}$, Nurul Hidayat ${ }^{1}$ \\ ${ }^{1}$ Institut Agama Islam Negeri Jember, Jl. Mataram No.1 Mangli, Jember 68136, \\ Jawa Timur, Indonesia \\ E-mail: dewihariyanti27@gmail.com
}

\begin{abstract}
Home learning policies lead to all educational institutions, including colleges organizing online learning. In its implementation, it was found various obstacles experienced by students during online learning, especially for biology students. This study aims to identify student barriers in implementing online biology learning during the Covid-19 pandemic. This research is a qualitative research with descriptive method. Data collection using closed questionnaires, interviews, and literature study. The research subjects were biology students at Jember colleges (both private and public), namely IAIN Jember, Jember University, Muhammadiyah University Jember, IKIP PGRI Jember, and Jember Islamic University. The results of the study indicate that the problems experienced by students in implementing online learning can be grouped into internal and external obstacles. The most dominant obstacles are obstacles originating from external factors namely internet quota and practicum implementation, and then internal factors that are quite inhibiting are students' understanding of the material.
\end{abstract}

Keywords: Bariers, student, online biology learning, covid-19

\begin{abstract}
Abstrak: Kebijakan belajar dari rumah menyebabkan semua lembaga pendidikan, termasuk perguruan tinggi menyelenggarakan pembelajaran secara daring. Dalam pelaksanaannya ditemukan berbagai hambatan yang dialami mahasiswa selama pembelajaran daring berlangsung, khususnya bagi mahasiswa biologi. Penelitian ini bertujuan untuk mengindentifikasi hambatan mahasiswa dalam pelaksanaan pembelajaran biologi secara daring selama pandemi Covid-19. Penelitian ini merupakan penelitian kualitatif dengan metode deskriptif. Pengumpulan data menggunakan angket tertutup, wawancara, dan studipustaka. Subjek penelitiannya adalah mahasiswa biologi di perguruan tinggi Jember (baik swasta maupun negeri)yaitu IAIN Jember, Universitas Jember, Universitas Muhammadiyah Jember, IKIP PGRI Jember, dan Universitas Islam Jember. Hasil dari penelitian menunjukkan bahwa permasalahan yang dialami mahasiswa dalam pelaksanaan pembelajaran daring dapat di kelompokkan menjadi hambatan internal dan eksternal. Hambatan yang paling dominan adalah hambatan yang berasal dari factor eksternal yaitu kuota internet dan pelaksanaan praktikum kemudian faktor internal yang cukup menghambat yaitu pemahaman mahasiswa terhadap materi.
\end{abstract}

Kata kunci: Hambatan, mahasiswa, pembelajaran biologi daring, covid-19

Pendidikan di Indonesia bertujuan untuk menciptakan manusia yang memiliki watak, karakter, dan kemampuan serta keterampilan (Depdiknas, 2003). Pendidikan sebagai bekal peserta didik agar siap beradaptasi dalam kehidupannya. Beberapa satuan pendidikan yang disediakan pemerintah seperti Sekolah Dasar (SD), Sekolah Menengah Pertama, Sekolah Menengah Atas (SMA), dan perguruan tinggi.

Perguruan tinggi bertugas membekali peserta didik agar siap di dunia pekerjaan dan menjalani kehidupannya. Penyusunan program pendidikan tinggi dilakukan untuk memenuhi kebutuhan tenaga kerja handal. Salah satu program pendidikan tinggi yaitu tingkat sarjana 
dengan kemampuan pemikiran yang logis, inovatif, dan kreatif serta dapat menyelesaikan masalah-masalah sekitarnya dengan memanfaatkan IPTEK. Selain itu. Lulusan strata-1 diharapkan mampu menerapkan dan mengaplikasikan ilmu masing-masing bidang. (Aswin, dkk: 2018)

Perguruan tinggi menyelenggarakan beberapa program studi bagi peserta didiknya. Program studi tersebut memiliki fokus terhadap bidang keilmuan tertentu. Salah satunya pendidikan biologi. Perkembangan biologi yang begitu pesat menuntut perkembangan cara berpikir, bersikap manusia Indonesia. Menghadapi masa depan penuh tantangan tersebut, proses belajar mengajar biologi diajarkan bukan sebagai produk berupa konsep atau prinsip, tetapi juga mendidik melalui biologi. Bekal pengetahuan biologi dapat diterapkan dalam kehidupan bermasyarakat yang harmonis dan sehat.(Tim Pengembangan Ilmu Pendidikan: 2007)

Perkuliahan dilakukan dengan tatap muka di kampus atau beberapa waktu tertentu juga dilakukan dengan e-learning. Namun dewasa ini diberbagai belahan dunia tengah terjadi pandemi Covid-19. Virus ini berkembang pertama kali di Wuhan, China. Namun, penyebaran virus ini sangat pesat ke seluruh penjuru dunia salah satu negara terdampak adalah Indonesia. Dalam menyikapi hal tersebut pemerintah Indonesia menerapkan kebijakan Work From Home (WFH) guna memutus mata rantai penyebaran virus Covid-19. Tentunya hal ini berdampak dalam berbagai sektor, salah satu diantaranya adalah pendidikan.(Rahmawati, dkk: 2020)

Adanya pembatasan dan kebijakan WFH, Kementerian Pendidikan juga memberlakukan kebijakan ini untuk setiap satuan pendidikan termasuk perguruan tinggi untuk melakukan proses pembelajaran secara daring dari rumah masing-masing. Perubahan secara mendadak ini menyebabkan gangguan psikologis bagi pendidik maupun peserta didik. Mereka harus beradaptasi dengan pelaksanaan pembelajaran secara daring selama pandemi ini berlangsung.

Bagi mahasiswa biologi perubahan ini cukup menjadi tantangan. Karena materi yang ditempuh cukup kompleks, tidak cukup dengan penjelasan belajar dengan teks tapi juga membutuhkan beberapa praktik baik di laboratorium maupun di lapang. Beberapa materi yang seharusnya dilakukan dengan praktik terpaksa tidak dilaksanakan karena alat maupun bahan yang terbatas. Minimnya akses internet bagi mahasiswa yang berasal dari desa juga menjadi hambatan dalam menerima materi yang didistribukan oleh dosen. Beberapa dosen juga mengalami keterbatasan dalam penyampaian materi sehingga tidak bisa memaksimalkan pemahaman materi kepada mahasiswa. Akibatnya mahasiswa juga tidak bisa menerima materi dengan baik. 
Berdasarkan uraian di atas terlihat banyak hambatan yang terjadi baik bagi pendidik maupun peserta didik. Dalam situasi ini juga seorang pendidik harus mengetahui hambatan hambatan yang dialami oleh peserta didik agar pembelajaran dapat berjalan dengan baik. Oleh karena itu, peneliti tertarik untuk meneliti hambatan pembelajaran biologi secara daring yang dialami oleh peserta didik khususnya mahasiswa biologi di masa pandemi Covid-19. Tujuan dalam penelitian ini adalah untuk mengidentikasi dan mendeskripsikan hambatan mahasiswa biologi dalam pelaksanaan pembelajaran biologi secara daring selama pandemi Covid-19.

\section{METODE}

Penelitian ini menggunakan pendekatan kualitatif dengan menggunakan metode deskriptif. Pendekatan yang digunakan ialah pendekatan survey. Pendekatan survey adalah metode penelitian deskriptif untuk memperoleh dan memaparkan data dari gejala-gejala yang ada serta menemukan keterangan-keterangan faktual tentang berbagai permasalahan yang berhubungan dengan pendidikan. (Wina, 2013: 67).

Teknik pengumpulan data menggunakan teknik triangulasi data. Menurut Sugiyono (2014) Triangulasi diartikan sebagai teknik pengumpulan data yang bersifat menggabungkan dari berbagai tekhnik pengumpulan data dan sumber yang telah ada. Bila peneliti mengumpulkan data dengan Triangulasi, maka sebenarnya peneliti mengumpulkan data yang sekaligus menguji kredibilitasnya. Dalam penelitian ini pengumpulan data menggunakan angket skala likert dengan pertanyaan negatif berbasis google form, wawancara dan study pustaka.

Subjek penelitiannya ialah mahasiswa biologi yang ada di perguruan tinggi jember yaitu IAIN Jember, Universitas Negeri Jember, Universitas Islam Jember, Universitas Muhammadiyah Jember dan IKIP PGRI Jember dengan jumlah responden sebanyak 108 mahasiswa dan untuk wawancara kita ambil 10 narasumber yang berasal dari perwakilan setiap perguruan tinggi.

Teknik analisis data pada angket tertutup pertanyaan negatif yaitu memberikan skor untuk masing-masing jawaban ( "Sangat Setuju" bernilai 1, "Setuju" bernilai 2, "Netral" bernilai 3, "Tidak Setuju" bernilai 3, "Sangat Tidak Setuju" bernilai 3). Selanjutnya, dilakukan perhitungan skor dan persentase rata-rata untuk setiap aspek menggunakan analisis deskriptif persentase. Kemudian, hasil angket dan wawancara dibandingkan dan juga di kaitkan dengan sumber dokumentasi. 


\section{HASIL}

Berikut adalah hasil dari persentase hambatan mahasiswa biologi dalam pembelajaran daring selama covid-19 :

Tabel 1. Persentase Hambatan Mahasiswa Biologi

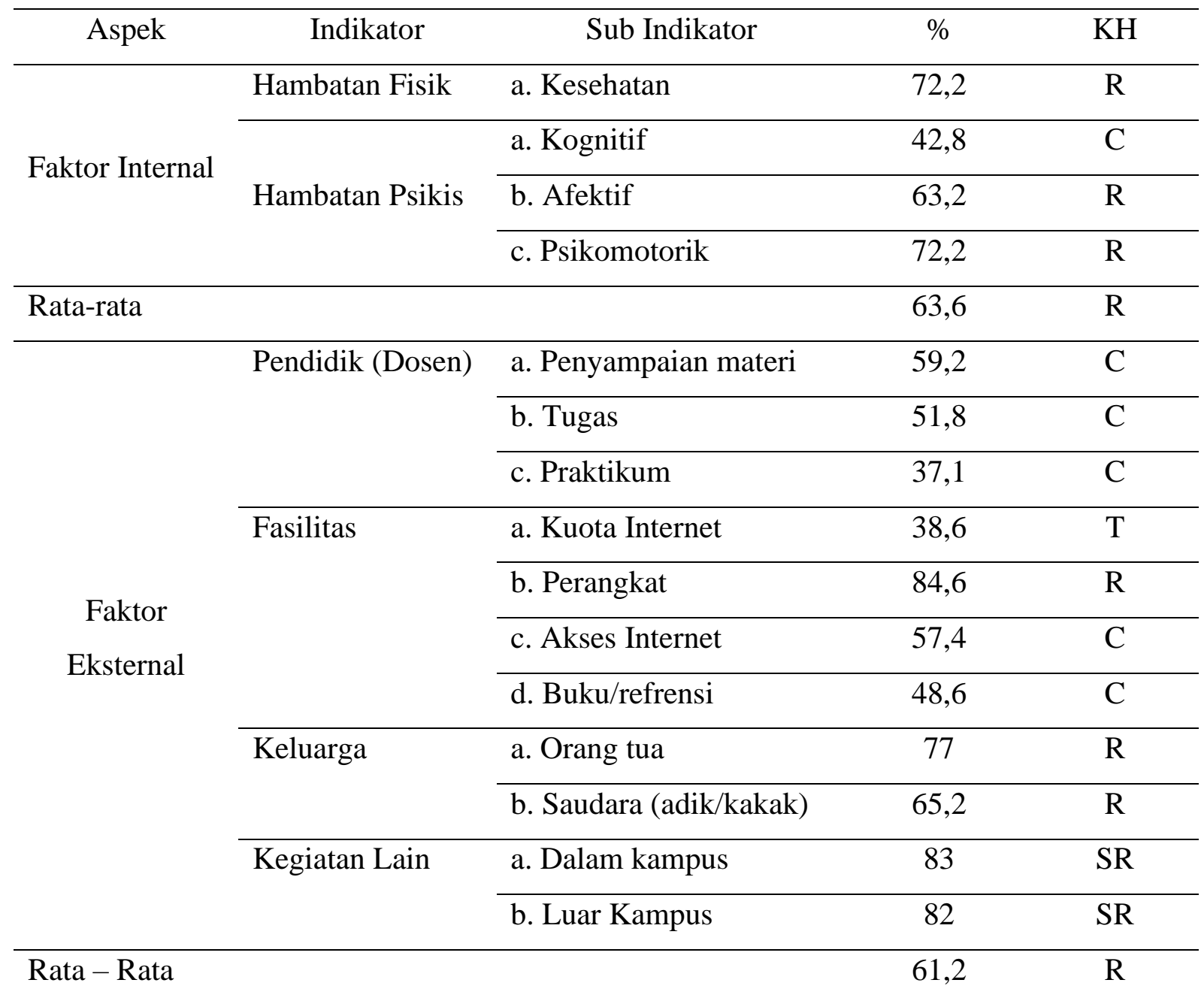

Catatan: KH = Kategori Hambatan

$\mathrm{SR}=$ Sangat Rendah

$\mathrm{R}=$ Rendah

$\mathrm{C} \quad$ = Cukup

$\mathrm{T} \quad=$ Tinggi

ST = Sangat Tinggi

Dari tabel diatas dapat diketahui bahwa hambatan tertinggi ialah ada pada keterbatasan kuota internet yaitu sebesar $(38,6 \%)$.Hambatan yang paling rendah ialah ada pada ketersediaan perangkat yaitu sebesar $(84,6 \%)$. Dan rata rata dari kedua faktor internal dan 
eksternal termasuk kategori hambatan rendah yaitu sebesar, faktor internal $(63,6 \%)$ dan faktor eksternal $(61,2 \%)$.

Hasil wawancara perwakilan mahasiswa biologi di perguruan tinggi kabupaten Jember sebanyak $10 \%$ dari jumlah responden dapat disimpulkan beberapa hambatan mahasiswa biologi dalam pembelajaran daring sebagai berikut:(1) Kuota dan akses Internet, menurut sebagian besar mahasiswa mengungkapkan bahwa kendala terbesar yang mereka alami ialah ketersedian kuota dan akses internet, karena menurut mereka kuota dan akses internet sangat penting dalam proses pembelajaran daring. Semua narasumber mengungkapkan ketika pembelajaran daring berlangsung tidak sedikit dari mereka yang kehabisan kuota internet dan akses internet yang susah karena jaringan terganggu yang pada akhirnya telat untuk absen, kesulitan mendownload materi dan pengumpulan tugas selalu gagal dan terhitung telat. (2) Fasilitas, mahasiswa mengungkapkan bahwa fasilitas berupa buku yang mereka punya sangat minim untuk menunjang perkuliahan mereka. Hal ini terjadi karena semua buku tertinggal di asrama/ kost dan tidak sempat untuk dibawa pulang. Akhirnya mereka mengalami kesulitan dalam penyusunan laporan praktikum pada saat dirumah. Untuk fasilitas selain buku seperti perangkat HP/ laptop sebagian besar dari mereka memiliki perangkat dan mampu mengoperasikannya untuk proses pembelajaran daring. (3) Pemahaman terhadap materi, berdasarkan wawancara yang dilakukan, sebagian besar mahasiswa mengeluhkan ketidakpahaman dalam memahami materi yang disampaikan dosen pada saat pembelajaran daring bahkan ada dosen yang tidak menjelaskan materi melainkan hanya memberi tugas sehingga tugas menumpuk. Selain itu, mahasiswa juga mengungkapkan bahwa pemahaman materi juga tergantung pada cara dosen dalam menyampaikan materi karena ada tipe dosen yang hanya menjelaskan dengan tulisan, mengirimkan pesan suara bahkan ada dosen yang membuat video pembelajaran untuk di pahami mahasiswanya dari hal inilah materi perkuliahan terkadang masih dapat di pahami dengan baik. (4) Kegiatan lain, mahasiswa mengungkapkan kegiatan lain selain perkuliahan juga menghambat dalam pembelajaran daring, misalnya mereka harus bekerja untuk membantu perekonomian orang tuanya sehingga merasa capek dan tidak jarang mereka meninggalkan kuliah, selain itu, keharusan membantu mengerjakan pekerjaan rumah juga menghambat dalam mengikuti proses pembelajaran daring. (5) Kesehatan, berdasarkan wawancara yang di lakukan mahasiswa mengungkapkan selama pembelajaran daring berlangsung mereka merasakan pusing dan mata panas karena belama lama di depan layar dan juga karena tugas yang banyak beserta deadline membuat 
mereka merasa kewalahan dan akhirnya jatuh sakit. Namun, ada juga yang mengungkapkan bahwa mereka tidak mengalami gangguan kesehatan karena selama berada dirumah nutrisi tercukupi dan dapat beristirahat dengan nyaman.

\section{PEMBAHASAN}

Proses perkuliahan dengan sistem daring memiliki beberapa hambatan, khususnya bagi mahasiswa biologi. Suatu hambatan adalah suatu objek, benda, kegiatan, atau situasi yang menyebabkan suatu halangan, menyebabkan kesulitan, gangguan atau suatu ketidakteraturan dalam rangka mencapai tujuan yang seharusnya(Wangid \& Sugiyanto, 2013). Penelitian diambil dari lima perguruan tinggi di Jember yaitu : Universitas Jember, IAIN Jember, IKIP PGRI Jember, Universitas Islam Jember, dan Universitas Muhammadiyah Jember, melalui angket berbasis google form. Angket ini berisi questioner dengan pernyataan negatif. Semakin tinggi hasil persentase, menunjukkan rendahnya hambatan mahasiswa dalam pembelajaran biologi secara daring.

Berdasarkan aspek hambatan pada dasarnya ada dua kemungkinan penyebab munculnya hambatan, yaitu:(a) Internal; (b) Ekstern(Wangid \& Sugiyanto, 2013). Hambatan internal meliputi hambatan fisik dan psikis, sedangkan aspek eksternal meliputi dosen, fasilitas, keluarga, dan kegiatan lain. Berdasarkan pilihan hambatan yang dialami responden dapat dipahami dua aspek hambatan yang dialami mahasiswa dikategorikan rendah. Rata-rata aspek internal 63,5\% dan aspek eksternal 61,2\% dengan kategori hambatan rendah artinya dua aspek ini tidak begitu besar hambatannya terhadap mahasiswa.

\section{a. Hambatan Internal}

Faktor penghambat pada aspek internal memiliki dua indikator yaitu hambatan fisik dan psikis. Persentase hambatan yang dialami mahasiswa didominasi hambatan psikis yang diketahui dari soal nomor 2, 4, dan 5. Hasil persentase paling rendah pada aspek kognitif 42,8\% dengan kategori hambatan cukup. Artinya, aspek kognitif ini menunjukkan bahwa pemahaman materi biologi cukup menghambat proses pembelajaran. Berdasarkan wawancara yang telah di lakukan Mahasiswa tidak dapat menyerap materi dengan baik. Dalam ranah kognitif, sejauh mana peserta didik dan pada level yang lebih atas seorang peserta didik mampu menguraikan kembali kemudian memadukannya dengan pemahaman yang sudah ia peroleh untuk kemudian diberi penilaian/pertimbangan.( M. M. Solichin, 2012). Berdasarkan hasil wawancara, alasan mahasiswa kesulitan dalam memahami materi ialah : (1) Cara dosen 
dalam menjelaskan materi kurang jelas, (2) Sebagian dosen yang tidak menjelaskan materi melainkan hanya memberi tugas, (3) Suasana hati yang mendukung.

Urutan kedua pada aspek afektif mahasiswa sebesar 63,2\% berkategori hambatan rendah. Aspek ini dilihat dari semangat dan motivasi mahasiswa yang minim. Daya saing antar sesama mahasiswa menurun karena mereka tidak berinteraksi secara langsung sehingga satu sama lain tidak termotivasi untuk belajar. Aryani (2013) menegaskan bahwa motivasi merupakan hal yang penting dalam proses pembelajaran. Motivasi yang dimiliki oleh siswa akan menentukan keberhasilan siswa untuk mencapai prestasi yang memuaskan. Selain itu, Gangguan kemalasan ketika berada di rumah kerap menjadi alasan mahasiswa.

Urutan ketiga sebesar 72,2\% yang dihasilkan oleh sub indikator psikomotorik dan sub indikator kesehatan yang merupakan hambatan fisik. Indikator psikomotorik tidak menjadi hambatan besar bagi mahasiswa. Keterampilan menggunakan perangkat elektronik saat perkuliahan secara daring berlangsung dapat diatasi dengan baik karena menurut wawancara yang telah dilakukan mereka sudah terbiasa mengoperasikannya. Sementara untuk hambatan fisik juga tidak menjadi hambatan yang besar berarti bagi mahasiswa.Berdasarkan hasil wawancarajustru dengan berada di rumah asupan makanan bergizi lebih mencukupi dari pada ketika perkuliahan normal berlangsung, istirahat juga cukup. Namun juga ada sebagian kecil mahasiswa yang sakit karena kurang istirahat saat mengerjakan tugas dan merasa pusing karena berada di depan layar.

Ketiga ranah di atas (kognitif, afektif, psikomotorik) yang lebih dikenal dengan istilah head (kepala), heart (hati), dan hand (tangan) merupakan kriteria yang dapat digunakan oleh pendidik untuk mengetahui tingakt keberhasilan proses pembelajaran.(Kasenda dkk, 2016)

\section{b. Hambatan Eksternal}

Hambatan faktor eksternal terdiri dari empat indikator yaitu: pendidik(dosen), fasilitas, keluarga, dan kegiatan lain. Indikator pendidik berkorelasi positif dengan aspek kognitif mahasiswa. Rendahnya pemahaman mahasiswa terhadap materi berbanding lurus dengan kurangnya kreativitas dosen dalam penyampaian materi dan penguasaan aplikasi yang digunakan untuk pembelajaran daring. Sub indikator lain yang dirasakan mahasiswa adalah tugastugas yang diberikan dosen tidak mampu memperdalam pemahaman mahasiswa. Dosen cenderung memberikan tugas yang banyak untuk mahasiswa tanpa melihat terlebih dahulu kadar pemahaman mahasiswa terhadap materi. Selanjutnya materi biologi juga membutuhkan praktik yang terkait dengan materi. Intruksi yang kurang jelas, keterbatasan alat dan bahan di ru- 
mah menghasilkan kategori hambatan tertinggi dengan persentase sebesar 37,1\% di antara sub indikator hambatan dari dosen(pendidik).Berdasarkan wawancara yang telah dilakukan, hambatan mahasiswa dalam pelaksanaan praktikum dirumah ialah (1) Buku/refrensi dalam menyusun laporan, (2) Kesulitan dalam mencari bahan praktikum.

Indikator hambatan yang kedua dilihat dari fasilitas yang dimiliki mahasiswa seperti kuota dan akses internet, perangkat penunjang pelajaran(hp, laptop, komputer), serta buku referensi. Hambatan tertinggi ada pada keterbatasan kuota internet dengan persentase sebesar 38,6\% hasil ini sesuai dengan hasil penelitian Dindin dkk. (2020) bahwa penghambat terbesar dalam pembelajaran daring di tengah pandemi covid-19 ini ialah kuota yang terbatas. Berdasarkan wawancara yang dilakukan, sebagian besar mahasiswa mengungkapkan kuota dan akses internet dapat menghambat dalam proses pembelajaran berlangsung. Kedua, minimnya buku referensi dengan persentase $48,6 \%$, berdasarkan wawancara yang telah dilakukan, alasan mahasiswa tidak memiliki referensi buku ialah karena sebagian besar dari mereka meninggalkan bukunya di kost dan tidak dapat diambil karena lockdown akibat pandemi Covid-19 ini. Ketiga, minimnya akses internet 57,4\%, menurut hasil wawancara akses internet dapat menghambat kegiatan pembelajaran daring, karena ada narasumber yang berada di daerah pelosok/ pedesaan yang akses internetnya minim. Namun, tidak sedikit pula yang akses internetnya lancar karena berada di daerah perkotaan atau menggunakan WI-fi dan yang paling baik nilai persentasenya adalah pada sub indikator minimnyaperangkat penunjang pembelajaran sebesar 84,6\%. Berdasarkan hasil wawancara, sebagian besar mahasiswa memiliki perangkat penunjang pembelajaran sehingga sub indikator ini tidak menjadi hambatan yang besar.

Hasil di atas sama dengan hasil penelitian Suryanti dkk. (2019) bahwa hambatan pembelajaran bagi mahasiswa biologi adalah terkait dengan bahan-bahan sumber belajar, yaitu tidak menemukan bahan-bahan sumber belajar yang memadai $(39,13 \%)$, tidak bisa memahami bahan-bahan sumber belajar yang ditemukan $(39,13 \%)$, dan tidak mampu mencari bahanbahan sumber belajar yang memadai $(21,74)$. Mastuti (2016) juga menegaskan bahwa salah satu faktor yang membuat siswa kehilangan konsentrasi ketika menghadapi sinyal atau jaringan internet yang tidak optimal. Perbedaan letak geografis tiap daerah berbeda-beda sehingga daya tangkap sinyal tidak sama. Misalnya mahasiswa yang letak rumahnya di desa yang jauh dari satelit internet, cuaca buruk, terlalu banyak bangunan tinggi menjulang. Akibatnya proses pembelajaran menjadi tertunda (delay) dan akhirnya memecah konsentrasi mahasiswa. 
Indikator ketiga adalah keluarga. Berdasarkan Surat Edaran Nomor 4 Tahun 2020 tentang Pelaksanaan Kebijakan Pendidikan Dalam Masa Darurat Penyebaran Corona Virus Disease (Covid-19) bahwa Proses Belajar dilakukan dari Rumah melalui pembelajaran daring/jarak jauh. Karena pembelajaran daring dilakukan dari rumah, perlu juga diamati bagaimana hambatan yang dialami mahasiswa yang berasal dari pihak keluarga. Dalam sebuah keluarga terdiri dari orang tua dan saudara (kakak/adik). Penilaian diambil dari respon mereka terhadap pembelajaran daring, apakah mendukung atau sebaliknya. Responden memberikan hasil tertinggi untuk dukungan orang tua selama pembelajaran daring. Sebagian besar orang tua mahasiswa dapat memahami dan mendukung proses pembelajaran. Hasil persentasenya sebesar $77 \%$ dikategorikan sebagai hambatan yang rendah bagi mahasiswa. Kemudian menyusul sub indikator yang kedua dari saudara baik kakak maupun adik. Hasil persentasenya juga dikategorikan rendah dengan persentase $65,2 \%$.

Indikator terakhir adalah kegiatan lain yang meliputi kegiatan dalam kampus maupun luar kampus. Indikator ini diamati seberapa besar kegiatan ini dapat menghambat proses pembelajaran mahasiswa sehingga dapat mengganggu fokus pembelajaran. Hasil persentasenya relatif sama. Kegiatan dalam kampus $83 \%$ dan kegiatan luar kampus 82\% dengan kategori hambatan sangat rendah. Artinya dua kegiatan ini tidak menggganggu fokus mahasiswa selama mengikuti pembelajaran biologi secara daring.Namun, berdasarkan hasil wawancara ada sebagian kecil mahasiswa yang memiliki kegiatan lain di luar kampus yaitu bekerja untuk memenuhi kebutuhan keluarga, sehingga mereka merasakan capek dan meninggalkan perkuliahan, hal ini terjadi kepada mahasiswa yang memiliki pengaruh besar dalam keluarga. Misalnya, sebagai tulang punggung keluarganya.

Temuan ini mendukung hasil penelitian sebelumnya bahwa mahasiswa yang bekerja akibatnya, aktivitas belajar menjadi berkurang secara signifikan karena waktu sudah banyak yang tersita untuk bekerja(Mardelina \& Ali, 2017). Temuan lain dari Glagah dan Sri Umi (2019) Mahasiswa yang bekerja part-time prestasi akademiknya menurun dilihat dari IPKmua karena kurang waktu untuk istirahat sehingga waktu kuliah dikorbankan untuk tidur di kelas.

Sebagian alasan mereka adalah karena pandemi Covid-19 pekerjaan orang tua menjadi terbatas sehingga penghasilan pun kurang memadai. Sehingga mereka harus turut bekerja untuk membiayai kebutuhan sendiri maupun keluarganya. Pada umumnya mereka berasal dari keluarga UMKM. Dalam paparannya kepada awak media melalui conference call Sri Mulyani mengatakan, "UMKM yang biasanya jadi safety net mengalami pukulan besar karena adanya 
restriksi kegiatan sosial. Ketika hadapi kondisi tahun 97-98 UMKM resilient, sekarang UMKM terpukul paling depan karena enggak ada kegiatan di luar rumah masyarakat."(Jadmiko, 2020)

\section{KESIMPULAN DAN SARAN}

\section{Kesimpulan}

Hambatan mahasiswa biologi dalam pelaksanaan pembelajaran biologi secara daring selama pandemi covid-19 ialah dapat dikelompokkan menjadi aspek faktor internal dan eksternal yaitu dengan indikator, hambatan fisik, psikis, pendidik (dosen), fasilitas, keluarga dan kegiatan lain. Secara umum, penghambat yang paling dirasakan oleh mahasiswa biologi ialah kuota internet, pelaksanaan praktikum dan pemahaman materi.

\section{Saran}

Mengacu pada hasil penelitian, (1) hendaknya pihak intitusi memberikan fasiltas kuota internet yang memadai bagi mahasiswa selama pembelajaran daring berlangsung, (2) model praktikum sebaiknya dirancang agar tidak terlalu memberatkan mahasiswa dan disesuaikan dengan keadaan selama pandemi ini, (3) pendidik hendaknya menggunakan metode pembelajaranyang mudah dipahami oleh mahasiswa, (4) bagi mahasiswa, agar dapat memahami materi hendaknya meningkatkan motivasi belajar dan menjauhi rasa malas.

\section{DAFTAR RUJUKAN}

Aswin, Pani, dkk. 2018. Studi Permasalahan Matakuliah Taksonomi Tumbuhan sebagai Landasan Pengembangan Pembelajaran pada Program Studi. Jurnal Pendidikan. Vol. 3, No. 11.

Jadmiko, Bambang P. Perekonomian Indonesian Pasca-Pandemi Covid-19. Kompas. 2020. https://money.kompas.com/read/2020/05/10/091500226/perekonomian-indonesiapasca-pandemi-covid-19?page $=3$

Jamaludin, Dindin dkk. Pembelajaran Daring Masa Pandemik Covid-19 Pada Calon Guru: Hambatan, Solusi Dan Proyeksi. Digital Library UIN Sunan Gunung Jati. 2020. http://digilib.uinsgd.ac.id/30518/

Kasenda, Lorenzo M. dkk. 2016. Sistem Monitoring Kognitif, Afektif dan Psikomotorik Siswa Berbasis Android. E-journal Teknik Informatika. Vol. 9, No. 1 
Mardelina, Elma \& Ali Muhson. 2017. Mahasiswa Bekerja Dan Dampaknya Pada Aktivitas Belajar Dan Prestasi Akademik. Jurnal Economia. Vol. 13, No. 2

Mastuti, E. 2016. Pemanfaatan Teknologi Dalam Menyusun Evaluasi Hasil Belajar : Kelebihan Dan Kelemahan "Tes Online” Untuk Mengukur Hasil Belajar Mahasiswa.Jurnal Penelitian Psikologi. Vol. 7, No. 1

Nurhidayati, Aryani. 2013. Peningkatan Hasil Belajar Ranah Afektif Melalui Pembelajaran Model Motivasional. Jurnal Iptek. Vol. 6, No. 2

Rahmawati, Diah Eka, dkk. 2020. Kompleksitas Pembelajaran Biologi Inovasinya Selama Pandemi Covid-19. Webinar Pendidikan 2020 : UNESA.

Sanjaya, Wina. 2013. Penelitian Pendidikan. Jakarta : Prenada Media Group

Sugiyono. 2014. Metode Penelitian Pendidikan Pendekatan Kuantitatif, Kualitatif dan R\&D. Bandung: Alfabeta

Suryanti, Evi ddk. 2019. Identifikasi Kesulitan Mahasiswa Dalam Pembelajaran Biologi Molekuler Berstrategi Modified Free Inquiry. Jurnal Perspektif Pendidikan dan Kegunaan. Vol. X, No. 2.

Solichin, M.M. 2012. Psikologi Belajar: Aplikasi Teori-Teori Belajar Dalam Proses Pembelajaran. Yogyakarta: Suka Press.

Tim Pengembangan Ilmu Pendidikan. 2007. Ilmu Dan Aplikasi Pendidikan. Pt Imtima: Bandung.

Wangid, Muhammad Nur \& Sugiyanto. 2013. Identifikasi Hambatan Struktural Dan Kultural Mahasiswa Dalam Menyelesaikan Tugas Akhir. Jurnal Penelitian Ilmu Pendidikan. Vol. 6, No. 2.

Yahya, Glagah Mahestiya, \& Sri Umi Mintarji Widjaja. 2019. Analisis Prestasi Akademik Pada Mahasiswa Yang Bekerja Part-Time Di Jurusan Ekonomi Pembangunan Fakultas Ekonomi Universitas Negeri Malang Angkatan 2014. Jurnal Pendidikan Ekonomi. Vol.12, No. 1 